\title{
Deaths from exposure to paramethoxymethamphetamine in Alberta and British Columbia, Canada: a case series
}

\author{
Jennifer J.E. Nicol MD, Mark C. Yarema MD, Graham R. Jones PhD, Walter Martz PhD, \\ Roy A. Purssell MD, Judy C. MacDonald MD MCM, Ian Wishart MD, Monica Durigon MSc, \\ Despina Tzemis MPH, Jane A. Buxton MBBS MHSc \\ Presented at the North American Congress of Clinical Toxicology, Sept. 1, 2013, Atlanta, GA
}

\section{Abstract}

Background: Paramethoxymethamphetamine (PMMA) is a ring-substituted amphetamine similar in structure to 3,4-methylenedioxymethamphetamine (MDMA or "ecstasy"), but substantially more toxic. We describe the clinical features of fatal exposures in the provinces of Alberta and British Columbia, Canada.

Methods: We conducted a retrospective case series on deaths in Alberta and BC between June 2011 and April 2012 for which forensic toxicologic analysis was positive for PMMA and the drug was implicated as the primary toxic agent. Data collected included patient demographics, exposure history, clinical features, investigations, therapy provided and postmortem toxicologic findings.

Results: A total of 27 PMMA-associated deaths (20 in Alberta, 7 in BC) were reported in the 11-month period. The median age was 24 (range 14-52) years, and 22 (81\%) were male. Ten patients were pronounced dead at the scene, and 17 died in hospital. The median time from exposure to death was 17 (range 5-264) hours. The median first-recorded vital signs (and ranges) were: heart rate 160 (86-201) beats/min, blood pressure 89/43 (69/30-162/83) mm Hg, respiratory rate 40 (26-48) breaths/min, oxygen saturation $81 \%(68 \%-100 \%)$ and temperature $39.4^{\circ} \mathrm{C}\left(34-43.8^{\circ} \mathrm{C}\right)$. Sixteen of the 17 people who died in hospital presented with clinical features consistent with serotonin syndrome. End-organ dysfunction included hepatic (30\%) and acute kidney injury (85\%), rhabdomyolysis $(54 \%)$, coagulopathy $(61 \%)$ and cardiac ischemia (15\%). Other drugs identified on toxicologic analysis were MDMA $(n=27)$, cocaine or its metabolite benzoylecgonine $(n=14)$ and methamphetamine $(n=12)$.

Interpretation: Exposure to PMMA was characterized by multiorgan dysfunction and serotonin syndrome, followed by cardiovascular collapse. In addition to PMMA, multiple synthetic amphetamines were present on toxicologic analysis. When evaluating patients suspected of exposure to sympathomimetic drugs of abuse, clinicians must anticipate multiple clinical effects from the increased release of dopamine, serotonin, norepinephrine and other neurotransmitters.

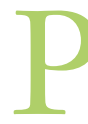
aramethoxymethamphetamine (PMMA) is a ringsubstituted amphetamine, similar in structure to 3,4-methylenedioxymethamphetamine (MDMA or "ecstasy") but substantially more toxic (Figure 1). ${ }^{1}$ With nearly 50 documented deaths in Europe, Asia, Australia and Israel, PMMA has earned the street names "Death" and "Dr. Death." Although the drug has been found in a small fraction of ecstasy pills confiscated during drug seizures, it is responsible for a disproportionate number of deaths. ${ }^{3}$ Clinical features include hyperthermia, serotonin syndrome and multiorgan dysfunction. ${ }^{2,4-8}$

Prior information on PMMA exposures has been limited to case reports or case series that focused on either the clinical or the postmortem features. Furthermore, descriptions of strategies adopted in response to outbreaks of PMMA-associated deaths are limited. Over an 11-month period from June 2011 to
April 2012, there were 27 confirmed deaths from exposure to ecstasy containing PMMA in the provinces of Alberta and British Columbia, Canada. We describe the clinical features observed with fatal PMMA exposures in Alberta and BC. We also describe the public health interventions that were implemented in response to the deaths, to provide an overview of the different services and organizations involved.

Competing interests: None declared.

This article has been peer reviewed.

Correspondence to: Jennifer Nicol, jjenicol@gmail.com

CMAJ Open 2015. DOI:10.9778/cmajo.20140070 


\section{Methods}

\section{Study design}

We conducted a retrospective case series of deaths in Alberta and BC between June 2011 and April 2012 for which forensic toxicologic analysis was positive for PMMA and the drug was implicated as the primary toxic agent on the antemortem or postmortem toxicologic analysis. The Office of the Chief Medical Examiner in Alberta and BC Coroners Service identified the cases (i.e., PMMA-associated deaths). The research ethics boards of the University of Calgary and the University of British Columbia approved the study. The need for informed consent was waived by both institutions.

\section{Data collection and definitions}

We reviewed the medical records of identified cases at the Office of the Chief Medical Examiner in Alberta (J.N. and I.W.) and BC Coroners Service (D.T.). Using a predefined medical-record review tool, we collected data on patient demographics, exposure history, clinical features, laboratory investigations, therapy provided and hospital course. We also obtained postmortem toxicology results and autopsy findings from the records. All measured laboratory values, including blood and tissue concentrations of PMMA and other substances, that had been obtained from the hospital records were also collected from the coroners' records. Time from exposure to hospital presentation was obtained for the patients who died in hospital. Time from exposure to death was obtained for those whose death was pronounced at the scene only if time of exposure and time of death were known.

Serotonin syndrome was defined as per the criteria of Dunkley and colleagues ${ }^{9}$ by the presence of neuromuscular abnormalities, mental status changes and hyperthermia. These criteria were applied only to patients who presented to hospital.

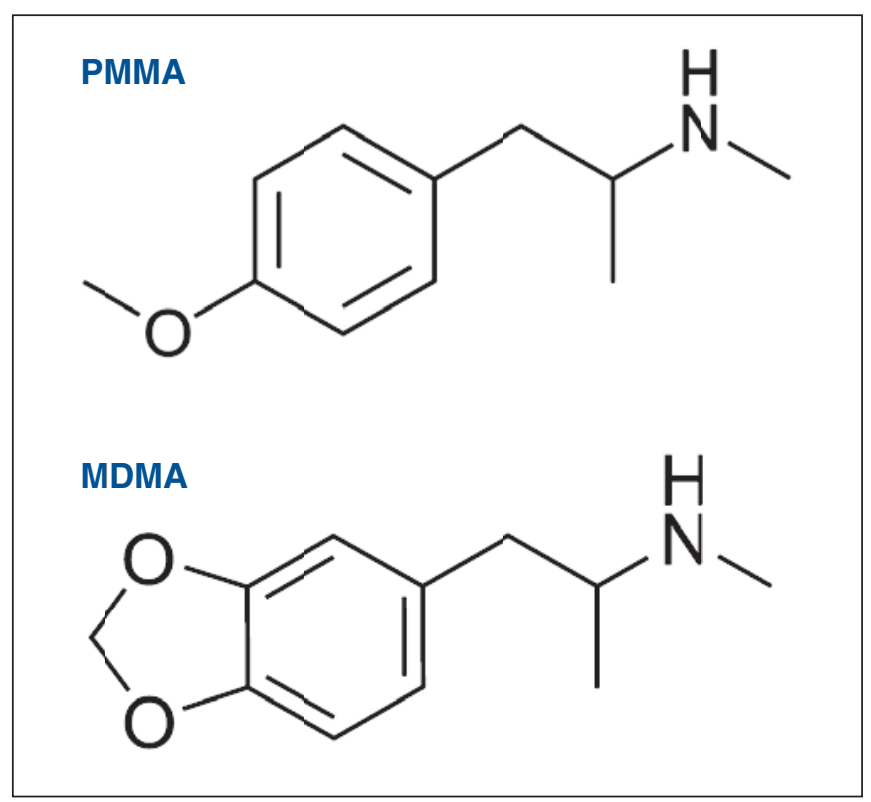

Figure 1: The chemical structures of paramethoxymethamphetamine (PMMA) and methylenedioxymethamphetamine (MDMA or "ecstasy").
Indicators of end-organ dysfunction were based on clinical findings, laboratory investigations and electrocardiogram (ECG) results. Hepatic injury was defined as a serum aspartate transaminase or alanine transaminase level greater than $1000 \mathrm{U} / \mathrm{L} .{ }^{10,11}$ Acute kidney injury was characterized by a rise in serum creatinine by at least $50 \%$ or at least $26.4 \mathrm{mmol} / \mathrm{L}$ from predicted baseline, or a urine output of less than $0.5 \mathrm{~mL} / \mathrm{kg}$ per hour over 6 hours. ${ }^{12}$ Rhabdomyolysis was defined as a creatine kinase level greater than $1000 \mathrm{U} / \mathrm{L}$ or more than 5 times the upper limit of normal. ${ }^{13}$ Coagulopathy was defined as an international normalized ratio of 1.3 or higher. Cardiac ischemia was characterized by the presence of ST-segment depression or elevation or T-wave inversion on ECG, or a serum troponin $\mathrm{T}$ level level greater than $0.03 \mu \mathrm{g} / \mathrm{L}$. Finally, sodium-channel blockade on ECG was characterized by a QRS duration greater than 120 ms and at least 1 of the following: a deep, slurred S wave in leads I and aVL; an R:S ratio greater than 0.7; or an $\mathrm{R}$ wave greater than $3 \mathrm{~mm}$ in lead aVR. ${ }^{14-16}$

\section{Toxicologic analysis}

Unless otherwise indicated, all Alberta cases were subject to testing for ethanol and related volatiles, plus comprehensive drug screening with a panel of enzyme-linked immunosorbent assays and broad-based gas chromatography with mass spectrometry. To quantify PMMA and related amphetamines, gas chromatography with mass spectrometry was used in selected ionmonitoring mode, after liquid-liquid extraction and derivatization with pentafluoroacetic anhydride. Matching deuterated internal standards were used for MDMA, methylenedioxyamphetamine, methamphetamine and amphetamine; MDMA- $\mathrm{d}_{5}$ was used as the internal standard for PMMA and paramethoxyamphetamine. The lower limit of quantitation for PMMA and all other amphetamines was administratively set at $0.05 \mathrm{mg} / \mathrm{L}$.

All cases in BC were tested for ethanol and related volatiles, plus comprehensive drug screening using liquid and broadbased gas chromatography with mass spectrometry. If urine was available, the TOX/See Drug Screen Test (Bio-Rad) was used. To quantify PMMA and related amphetamines, liquid chromatography with mass spectrometry (4000 QTRAP, AB Sciex) was used in selected ion-monitoring mode, after precipitation with acetonitrile without derivatization. Matching deuterated internal standards were used for MDMA, methylenedioxyamphetamine, methamphetamine and amphetamine; amphetamine- $\mathrm{d}_{5}$ was used as the internal standard for PMMA and paramethoxyamphetamine. The lower limit of quantitation for PMMA and all other amphetamines was administratively set at $0.01 \mathrm{mg} / \mathrm{L}$.

\section{Statistical analysis}

Microsoft Excel version 14.3.7 was used for data entry and analysis. We report median values with ranges for clinical features, toxicologic findings and postmortem autopsy findings.

\section{Results}

A total of 27 PMMA-associated deaths (20 in Alberta and 7 in BC) occurred in the 11-month period. Patient characteristics are summarized in Table 1. The median age was 24 (range 
Table 1: Summary of 27 deaths associated with the use of paramethoxymethamphetamine (PMMA) in Alberta and British Columbia, June 2011 to April 2012

\begin{tabular}{|c|c|c|c|}
\hline Case & $\begin{array}{l}\text { Location and circumstances } \\
\text { around presentation and death }\end{array}$ & $\begin{array}{l}\text { Drug(s) believed to } \\
\text { have been consumed }\end{array}$ & Postmortem findings \\
\hline 1 & Took drugs at home; became unwell, friend called 911; died in ER & Ecstasy & Pulmonary edema, CAD \\
\hline 2 & $\begin{array}{l}\text { Took ecstasy alone; found } 9 \text { hours later; died in ER after unsuccessful } \\
\text { resuscitation }\end{array}$ & Ecstasy & Rapid rigor mortis \\
\hline 3 & Took pills alone, felt unwell and self-presented to ER; died in ICU & Ecstasy & Cerebral edema, pulmonary edema \\
\hline 4 & $\begin{array}{l}\text { Took ecstasy with friends; became unresponsive; transported to ER in private } \\
\text { vehicle; died in ICU }\end{array}$ & Ecstasy & Cerebral edema, ascites, pleural effusion \\
\hline 5 & $\begin{array}{l}\text { At house party after taking drugs; became unresponsive; transported to } \\
\text { hospital via EMS; died in ICU }\end{array}$ & Ecstasy & Rhabdomyolysis \\
\hline 6 & $\begin{array}{l}\text { Found unresponsive at house party; transported to hospital via EMS; had } \\
\text { cardiac arrest, died in ICU }\end{array}$ & Ecstasy, alcohol & No autopsy \\
\hline 7 & $\begin{array}{l}\text { At house party; found unresponsive after last seen } 1.5 \text { hours earlier; } \\
\text { transported to hospital via EMS, had cardiac arrest; died in ICU }\end{array}$ & Ecstasy & No autopsy \\
\hline 8 & Found dead in bed at home & Unknown & Trivial soft-tissue abrasions \\
\hline 9 & $\begin{array}{l}\text { At house party with friends; became unwell; cardiac arrest after intubation with } \\
\text { EMS; died in ICU }\end{array}$ & 8 tabs of ecstasy & Lung congestion, patchy pneumonia \\
\hline 10 & $\begin{array}{l}\text { Watching live performance; became unwell; cardiac arrest with EMS; died in } \\
\text { ER after unsuccessful resuscitation }\end{array}$ & $\begin{array}{l}\text { 1-2 g of MDMA, } \\
\text { cocaine }\end{array}$ & Cardiomegaly, spleen congestion \\
\hline 11 & At nightclub; became unwell; transported to ER in private vehicle; died in ICU & $\begin{array}{l}6 \text { tablets of MDMA, } \\
\text { hallucinogenic } \\
\text { mushrooms, LSD }\end{array}$ & No autopsy \\
\hline 12 & Found dead at home & Unknown & $\begin{array}{l}\text { Pulmonary congestion, cerebral edema, } \\
\text { mottled myocardium, cardiomegaly }\end{array}$ \\
\hline 13 & $\begin{array}{l}\text { Friend noticed patient acting abnormally; transported to hospital in private } \\
\text { vehicle after seizure; died in ER }\end{array}$ & $\begin{array}{l}2 \text { snorts of MDMA/ } \\
\text { ecstasy powder }\end{array}$ & Congestion of heart, lungs and liver \\
\hline 14 & $\begin{array}{l}\text { Took drugs at house party; found unconscious outside at nearby property; died } \\
\text { in ER after unsuccessful resuscitation }\end{array}$ & $\begin{array}{l}\text { Unknown amount of } \\
\text { white powder believed } \\
\text { to be ecstasy }\end{array}$ & $\begin{array}{l}\text { Congestion of heart, lungs, liver and } \\
\text { spleen, cerebral edema }\end{array}$ \\
\hline 15 & $\begin{array}{l}\text { At a bar with friends; that night at home had a witnessed seizure, followed by } \\
\text { cardiac arrest; pronounced dead upon EMS arrival }\end{array}$ & Unknown & $\begin{array}{l}\text { Pulmonary edema, congestion of heart, } \\
\text { liver and spleen, cerebral edema }\end{array}$ \\
\hline 16 & $\begin{array}{l}\text { Took } 2 \text { doses of ecstasy at bar; began acting strange upon return home with } \\
\text { friends; had seizure en route to hospital with EMS, and cardiac arrest in ER; } \\
\text { died in ER after unsuccessful resuscitation }\end{array}$ & 2 pills of ecstasy & $\begin{array}{l}\text { Pulmonary edema, kidney and spleen } \\
\text { congestion, interstitial hemorrhage in heart }\end{array}$ \\
\hline 17 & At home with friends drinking and taking drugs; found dead the next morning & $\begin{array}{l}\text { Cocaine, MDMA, } \\
\text { alcohol }\end{array}$ & Fatty liver, unremarkable post mortem \\
\hline 18 & $\begin{array}{l}\text { At a house party; felt unwell, called } 911 \text {; cardiac arrest soon after EMS arrival; } \\
\text { died in ER after unsuccessful resuscitation }\end{array}$ & $\begin{array}{l}\text { Unknown white powder } \\
\text { snorted }\end{array}$ & $\begin{array}{l}\text { Rib and sternal fractures, pulmonary } \\
\text { edema, advanced cirrhosis, enlarged } \\
\text { spleen }\end{array}$ \\
\hline 19 & $\begin{array}{l}\text { Took MDMA powder the night before; felt unwell; found unresponsive the next } \\
\text { afternoon; pronounced dead with EMS }\end{array}$ & $\begin{array}{l}1.5 \mathrm{~g} \text { of MDMA rolled in } \\
\text { paper and ingested }\end{array}$ & Cerebral and pulmonary edema \\
\hline 20 & $\begin{array}{l}\text { Took drugs throughout the night at home; had cardiac arrest; died in ER after } \\
\text { unsuccessful resuscitation }\end{array}$ & MDMA, cocaine & $\begin{array}{l}\text { Pulmonary congestion, cardiomegaly, } \\
\text { nephrosclerosis }\end{array}$ \\
\hline 21 & At party the night before with friends; found dead at home the next day & Ecstasy, cocaine & $\begin{array}{l}\text { Edema and congestion of lungs, liver, } \\
\text { spleen and kidneys }\end{array}$ \\
\hline 22 & Last seen 3 days earlier; police/EMS attended; pronounced dead at the scene & Unknown & Pulmonary congestion \\
\hline 23 & $\begin{array}{l}\text { Partying with friends the night before; no history of drug use; found dead the } \\
\text { next day }\end{array}$ & Unknown & Pulmonary edema \\
\hline 24 & Last seen 3 days prior. Police/EMS attended, dead on scene. & Cocaine, alcohol & Congestion of lung, liver, spleen and kidneys \\
\hline 25 & $\begin{array}{l}\text { At house party; took multiple doses of MDMA through the night by snorting } \\
\text { and ingestion; became confused and unresponsive; friends called } 911 \text {; died in } \\
\text { ER after unsuccessful resuscitation }\end{array}$ & $0.5 \mathrm{~g}$ of MDMA & Pulmonary congestion \\
\hline 26 & $\begin{array}{l}\text { At party with friends; EMS called; cardiac arrest after intubation; resuscitated in } \\
\text { ER, died in ICU }\end{array}$ & 7 tabs of MDMA & No autopsy \\
\hline 27 & At concert; took drugs and alcohol; pronounced dead at home with EMS & MDMA, cocaine, alcohol & No autopsy \\
\hline
\end{tabular}


14-52) years, and 22 (81\%) were male. Twelve (44\%) had a reported history of illicit drug use. Ten (37\%) were pronounced dead at the scene, 10 (37\%) died in the emergency department, and 7 (26\%) died after admission to the intensive care unit (ICU). The median time from exposure to hospital presentation was 6 (range 1.5-16.5) hours, and from exposure to death 17 (range 5-264) hours. In most cases, there was a delay in seeking medical care from the time a problem was identified by friends or family. The route of administration was unknown in most cases; among those for whom the route was known, most believed they were using ecstasy powder or pills.

The median first-recorded vital signs (and ranges) were: heart rate 160 (86-201) beats/min, blood pressure 89/43 (69/30-162/83) mm Hg, respiratory rate 40 (26-48) breaths/ min, oxygen saturation $81 \%(68 \%-100 \%)$ and temperature $39.4^{\circ} \mathrm{C}\left(34-43.8^{\circ} \mathrm{C}\right)$. Sixteen $(94 \%)$ of the 17 patients who died in hospital presented with clinical features consistent with serotonin syndrome. Three (11\%) of the 27 patients experienced seizures. Among the 17 who died in hospital, there were multiple indicators of end-organ dysfunction (Figure 2). Evidence of cardiac sodium-channel blockade was present in 1 patient whose toxicologic analysis was negative for known sodium-channel blocking agents. The median recorded laboratory values are highlighted in Table 2. Interventions for the 17 patients transported to hospital are shown in Table 3.

Results of the toxicologic analyses are summarized in Table 4. Substances other than PMMA were detected in all patients, the most common being MDMA $(n=27)$, cocaine or its metabolite benzoylecgonine $(n=14)$ and methamphetamine $(n=12)$. The median antemortem and postmortem whole blood PMMA concentrations are reported in Table 5. Postmortem findings are summarized in Table 1.

\section{Interpretation}

We describe a large case series of 27 PMMA-associated deaths in 2 provinces over an 11-month period. Exposure to PMMA was characterized by multiorgan dysfunction, shock and serotonin syndrome, followed by cardiovascular collapse and death. Most of the patients died in hospital following a delay in presenting to the emergency department. Severe hyperthermia, hyperkalemia and hypoglycemia were present in most cases. Notable autopsy findings included pulmonary and cerebral edema. In addition to PMMA, multiple synthetic amphetamines were found in the toxicologic analysis in all patients.

The effect of PMMA is mediated primarily through the release of serotonin, and to a lesser extent dopamine, from presynaptic neurons. ${ }^{18}$ PMMA is more similar in structure to MDMA than to amphetamine, yet influx into the brain is delayed compared with MDMA, which results in later onset of psychological effects. ${ }^{19,20}$ PMMA has several active metabolites, including paramethoxyamphetamine and pholedrine. ${ }^{21}$ It has a narrow margin of safety, with a two- to fourfold difference between the stimulant-producing and lethal doses observed in rats. ${ }^{1}$ Hyperthermia from use of the drug is secondary to both serotonin syndrome and monoamine oxidase inhibition, and toxicity is increased in crowded conditions because of an accelerated rate of temperature change and longer duration of hyperthermia. ${ }^{20}$ The delayed onset of desired effects may lead to frequent and early redosing, which increases the risk of lifethreatening toxicity.

The clinical presentation we have described is consistent with previous published reports. The first reported PMMA-associated death occurred in Spain in 1993, followed by 3 deaths in Denmark in 2003, 1 in Germany in 2003, 8 in Taiwan in 2006, 24 in Israel from 2007 to 2008, and most recently 22 nonfatal and 12 fatal cases in Norway from 2010 to 2011 . $^{27,18}$ There

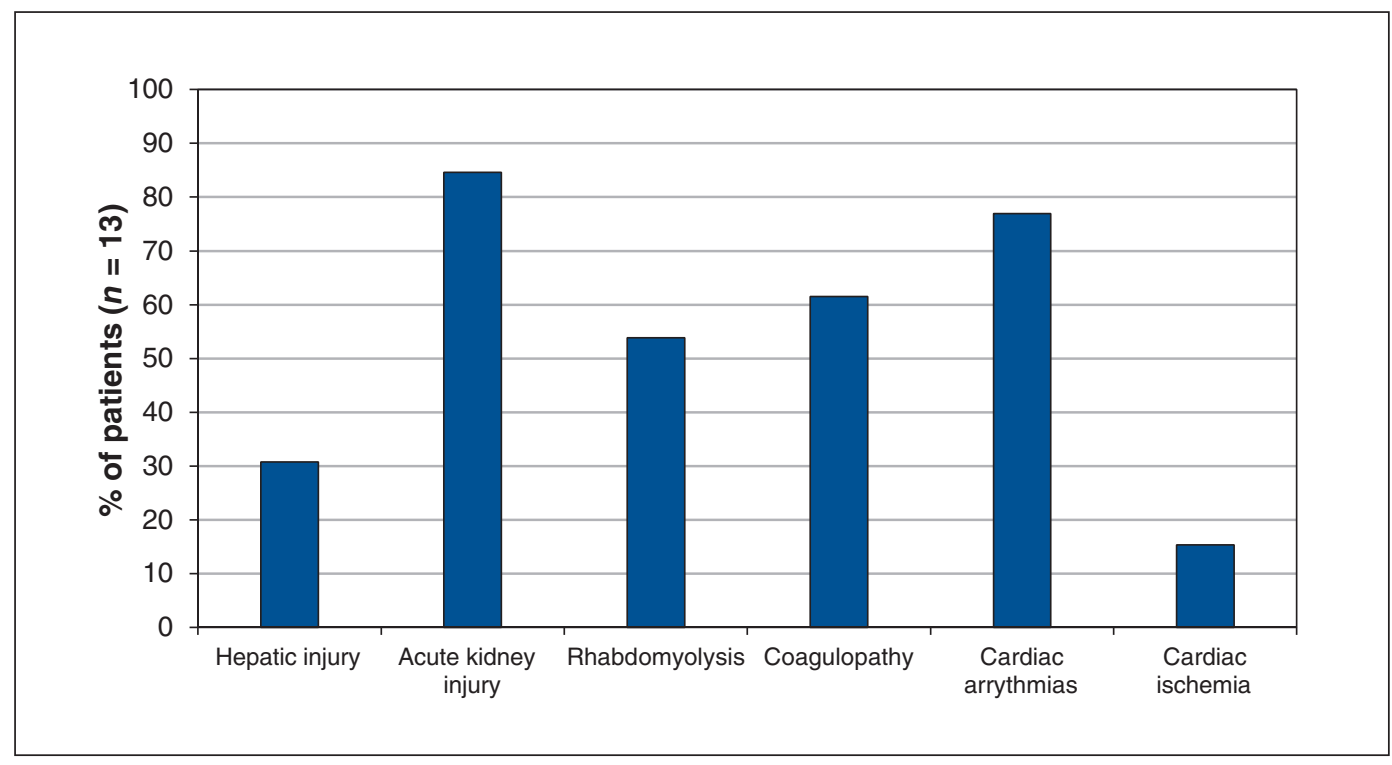

Figure 2: Antemortem end-organ dysfunction based on clinical findings and investigations of 13 of the 17 patients who died in hospital. Data were missing for 4 patients who were pronounced dead shortly after arrival in the emergency department [no antemortem investigations performed]. 
have, however, been PMMA-associated deaths since 2012 that have not appeared in the medical literature. Compared with our patients, a higher proportion of individuals in the previous reports died before reaching hospital, and there were fewer instances of exposure to additional synthetic amphetamines on toxicologic analysis. The PMMA concentrations in our series are similar to those previously reported.

The public health response to the PMMA-associated deaths in our series involved extensive collaboration among law enforcement, health services, emergency medical services, poison control centres, public health agencies, and the Office of the Chief Medical Examiner in Alberta and BC Coroners Service. In Alberta, a working group was created in early 2012, cochaired by senior public health, addictions and mental health leaders, and the medical director of the Poison and Drug Information Service. In BC, the BC Drug Overdose and Alert Partnership Committee, chaired by the $\mathrm{BC}$ Centre for Disease Control, facilitated the coordinated response between the various parties. The Alberta Poison and Drug Information Service, $\mathrm{BC}$ ambulance and the $\mathrm{BC}$ Drug and Poison Information Centre developed clinical management guidelines for MDMA and other sympathomimetic drugs of abuse, and the regional health authorities developed alerts for health care professionals (Appendix 1, available at www.cmajopen.ca/content/3/1/E83/suppl/DC1).

Through the use of media interviews, print materials, a "one-stop" PMMA website and social media (Facebook and Twitter), information was disseminated to the public, educators, universities and community agencies (Appendix 2, available at www.cmajopen.ca/content/3/1/E83/suppl/DC1). ${ }^{22}$ Public health and law enforcement actively reached out to school and university populations, and targeted DanceSafe and online drug-user forums. The Office of the Provincial Health Officer along with the BC Coroners Service and law enforcement coordinated public announcements and media inquiries.

The reach of the collaborative messaging included coverage in regional and national newspapers and websites, and television coverage by national networks. ${ }^{23-27}$ The American Association of Poison Control Centers released an alert on the deaths to all 55 poison centres in the United States. Multiple

\begin{tabular}{|c|c|c|}
\hline Investigation & Level, median (range) & $\begin{array}{l}\text { Normal } \\
\text { range† }\end{array}$ \\
\hline Peak potassium, mmol/L & $7.0(4.4-12.5)$ & $3.5-5.1$ \\
\hline Peak creatinine, $\mathrm{mmol} / \mathrm{L}$ & $214(146-1127)$ & $50-110$ \\
\hline Peak AST, U/L & $2944(116-5124)$ & $7-40$ \\
\hline Peak creatinine kinase, $\mathrm{U} / \mathrm{L}$ & 8200 (1952-237 960) & $38-215$ \\
\hline $\begin{array}{l}\text { Lowest recorded glucose, } \\
\mathrm{mmol} / \mathrm{L}\end{array}$ & $1.9(0.4-17.1)$ & $3.9-6.1$ \\
\hline \multicolumn{3}{|c|}{$\begin{array}{l}\text { Note: AST = aspartate transaminase. } \\
\text { "Data missing for } 4 \text { patients; they were pronounced dead shortly after arrival to } \\
\text { the emergency department (no antemortem investigations). } \\
\text { †Normal values were obtained from the Royal College of Physicians and } \\
\text { Surgeons of Canada. }{ }^{17}\end{array}$} \\
\hline
\end{tabular}

drug-user forums and blogs reported on the harmful effects of PMMA based on the advisories issued in Alberta and BC. ${ }^{28-34}$ The messaging was included on a medical toxicology review blog "The Poison Review" as part of a series on PMMA..$^{35}$

The coordinated public health response, and sharing of information among public health agencies, poison control centres, regional health services, the Office of the Chief Medical Examiner, the BC Coroners Service, and law enforcement in Alberta and BC played a role in the eventual decline in PMMA-associated deaths in both provinces. Although it cannot be shown that the public health response directly caused the decline in deaths, it did enable open communication among the key parties, which resulted in information dissemination and media attention. It is also difficult to identify which components of the public health response were most effective, because they were aimed at different populations. Other potential reasons for a decline in PMMA-associated deaths include the cessation of PMMA production by those manufacturing ecstasy, reduced dissemination of PMMA by drug dealers and the reduction of ecstasy consumption use by drug-using populations. ${ }^{36}$ Finally, there may have been unintended consequences of the public health messaging, including a shift from the use of ecstasy to more dangerous drugs of abuse by at-risk teens, nightclub users and street-involved adults. ${ }^{37}$

The finding of multiple sympathomimetic drugs in the antemortem and postmortem specimens emphasizes the variability in the content of ecstasy powder and pills produced in clandestine laboratories. ${ }^{38,39}$ In addition, the potential for exposure to numerous sympathomimetic drugs of abuse has implications when evaluating patients. Clinicians must anticipate multiple clinical effects from the increased release of dopamine, serotonin, norepinephrine and other neurotransmitters. Because the precise drug content of ecstasy is often unknown to the user, there is an increasing availability of drug-testing kits at mass gatherings such as raves and music festivals. ${ }^{40}$ Future research is needed to examine whether these kits help the purchaser understand and appreciate the content before exposure.

Table 3: Therapies provided by emergency medical services or in hospital for patients transported to hospital $(n=9 / 17)^{*}$

\begin{tabular}{|lcc|}
\hline Therapy & No. (\%) of patients \\
\hline Intubation & 9 & $(100)$ \\
\hline Paralysis & 6 & $(67)$ \\
\hline Sedation & 5 & $(56)$ \\
\hline Cooling & & \\
\hline Ice packs & 4 & $(44)$ \\
\hline Cooled intravenous fluid & 2 & $(22)$ \\
\hline Cyproheptadine & 1 & $(11)$ \\
\hline Cooling blanket & 1 & $(11)$ \\
\hline Cooling catheter & 1 & $(11)$ \\
\hline *Data missing for 8 patients. & & \\
\hline
\end{tabular}




\section{Limitations}

Our study has several limitations. First, we collected data retrospectively from medical records at the Office of the Chief
Medical Examiner and BC Coroners Service rather than from hospital records. This resulted in missing data, especially therapies provided. Because of the geographic distribution of

Table 4: Results of toxicologic analysis

\begin{tabular}{|c|c|c|c|c|c|c|c|c|c|c|}
\hline \multirow[b]{2}{*}{ Case } & \multirow[b]{2}{*}{ Specimen type } & \multicolumn{8}{|c|}{ Toxin, mg/L } & \multirow[b]{2}{*}{ Other findings* } \\
\hline & & PMMA & PMA & MDMA & MDA & MAMP & AMP & Cocaine & BE & \\
\hline 1 & Postmortem blood $\dagger$ & 1.6 & 0.17 & 2.3 & 0.12 & 0.84 & 0.024 & ND & ND & Lidocaine \\
\hline 2 & Postmortem blood $\dagger$ & NSQ & NSQ & 3.9 & 0.12 & ND & ND & 0.38 & 3.9 & $\begin{array}{l}\text { PMMA vitreous } 0.69 \mathrm{mg} / \mathrm{L} ; \text { MDMA } \\
\text { vitreous } 1.4 \mathrm{mg} / \mathrm{L} \text {; cannabinoids }\end{array}$ \\
\hline 3 & Antemortem blood $\dagger$ & 1.2 & 0.093 & 0.99 & 0.036 & ND & ND & ND & 0.32 & \\
\hline 4 & Antemortem blood $\dagger$ & 1.6 & 0.098 & 0.52 & 0.021 & ND & ND & ND & ND & Lorazepam \\
\hline 5 & Postmortem blood $\dagger$ & 1.8 & ND & 0.6 & ND & ND & ND & ND & ND & Morphine, lidocaine, cannabinoids \\
\hline 6 & Antemortem blood $\dagger$ & 0.11 & 0.023 & 0.14 & 0.015 & ND & ND & ND & ND & $\begin{array}{l}\text { Midazolam, temazepam, rocuronium } \\
\text { metabolite, acetaminophen }\end{array}$ \\
\hline 7 & Antemortem blood $\dagger$ & URP & URP & 0.32 & ND & ND & ND & ND & ND & \\
\hline 8 & Postmortem IVC blood & 3.33 & 0.42 & 3.09 & 0.17 & 2.28 & 0.07 & ND & ND & $\begin{array}{l}\text { Dextromethorphan } 0.66 \mathrm{mg} / \mathrm{L} \text {, } \\
\text { acetaminophen } 18.2 \mathrm{mg} / \mathrm{L} \text {, } \\
\text { ketamine, oxycodone }\end{array}$ \\
\hline \multirow[t]{2}{*}{9} & Antemortem serum $\dagger$ & 0.94 & 0.07 & 0.09 & Trace & 0.3 & Trace & ND & ND & \\
\hline & Postmortem IVC blood & 0.14 & Trace & Trace & Trace & 0.11 & Trace & ND & ND & \\
\hline \multirow[t]{2}{*}{10} & Antemortem blood $\dagger$ & 2.28 & 0.1 & 0.31 & Trace & 0.75 & Trace & ND & 0.19 & \\
\hline & Postmortem femoral blood & 4.41 & 0.25 & 0.6 & Trace & 1.47 & Trace & Trace & 0.26 & \\
\hline 11 & Antemortem blood $\dagger$ & 0.44 & 0.08 & Trace & Trace & 0.18 & Trace & TNP & TNP & $\begin{array}{l}\text { Drug screen not performed (limited } \\
\text { specimen) }\end{array}$ \\
\hline 12 & Postmortem IVC blood & 3.74 & 0.11 & 1.64 & Trace & ND & ND & ND & ND & Ethanol $30 \mathrm{mg} / 100 \mathrm{~mL}$ \\
\hline \multirow[t]{2}{*}{13} & Antemortem blood $\dagger$ & 1.25 & 0.07 & 0.11 & Trace & 0.35 & Trace & ND & 0.11 & \\
\hline & Postmortem IVC blood & 2.67 & 0.18 & 0.26 & Trace & 0.8 & Trace & ND & 0.17 & \\
\hline \multirow[t]{2}{*}{14} & Postmortem IVC blood & 2.7 & 0.12 & 0.29 & Trace & 0.86 & Trace & ND & ND & \\
\hline & Postmortem central blood & 4.35 & 0.18 & 0.43 & Trace & 1.28 & 0.05 & ND & ND & \\
\hline 15 & Postmortem IVC blood & 2.97 & 0.08 & 0.32 & Trace & ND & ND & 0.04 & 0.3 & $\begin{array}{l}\text { Acetaminophen } 10.6 \mathrm{mg} / \mathrm{L} \text {, codeine } \\
0.07 \mathrm{mg} / \mathrm{L} \text {, atropine }\end{array}$ \\
\hline 16 & Postmortem IVC blood & 1.67 & 0.15 & 0.27 & Trace & 0.63 & Trace & Trace & 0.2 & $\begin{array}{l}\text { Oxycodone (trace), delta-9- } \\
\text { tetrahydrocannabinol } 2.3 \mathrm{ng} / \mathrm{mL} \text {, } \\
\text { carboxy- tetrahydrocannabinol } \\
11.8 \mathrm{ng} / \mathrm{mL}\end{array}$ \\
\hline 17 & Postmortem IVC blood & 4.88 & 0.22 & 1.12 & 0.04 & 1.78 & 0.06 & 0.08 & 0.84 & Levamisole, phenacetin \\
\hline 18 & Postmortem femoral blood & 3.56 & 0.33 & 1.7 & 0.12 & Trace & ND & ND & 0.67 & Benzylpiperazine \\
\hline 19 & Postmortem central blood & 0.65 & 0.06 & 2.58 & 0.06 & ND & ND & ND & ND & Ethanol $10 \mathrm{mg} / 100 \mathrm{ml}$. \\
\hline 20 & Postmortem femoral blood & 15.7 & 0.75 & 0.65 & Trace & ND & ND & ND & ND & Diphenhydramine \\
\hline 21 & Postmortem femoral blood & 6.19 & 0.51 & 0.26 & Trace & ND & ND & ND & ND & Dextromethorphan \\
\hline 22 & Postmortem iliac blood & 5.36 & 1.08 & 0.6 & 0.05 & 1.45 & 0.1 & Trace & 0.11 & Oxycodone $2.01 \mathrm{mg} / \mathrm{L}$, ibuprofen \\
\hline 23 & Postmortem femoral blood & 6.34 & 0.23 & 0.34 & Trace & ND & ND & Trace & 1.16 & $\begin{array}{l}\text { Benzylpiperazine } 1.65 \mathrm{mg} / \mathrm{L} \text {, TFMPP } \\
0.47 \mathrm{mg} / \mathrm{L} \text {, ketamine, levamisole }\end{array}$ \\
\hline 24 & Postmortem femoral blood & 3.58 & 0.23 & 0.16 & Trace & ND & ND & ND & ND & $\begin{array}{l}\text { Benzylpiperazine } 1.00 \mathrm{mg} / \mathrm{L} \text {, TFMPP } \\
0.15 \mathrm{mg} / \mathrm{L}\end{array}$ \\
\hline 25 & Antemortem blood $\dagger$ & 1.6 & 0.1 & 0.14 & Trace & 0.47 & Trace & Trace & 1.09 & Ketamine $0.71 \mathrm{mg} / \mathrm{L}$, midazolam \\
\hline \multirow[t]{2}{*}{26} & Antemortem blood $\dagger$ & 3.27 & 0.09 & 0.16 & Trace & ND & ND & Trace & 0.53 & \\
\hline & Postmortem iliac blood & 3.83 & 0.14 & 0.19 & Trace & ND & ND & Trace & 0.55 & \\
\hline 27 & Postmortem iliac blood & 2.17 & 0.08 & 1 & Trace & ND & ND & 0.05 & 0.46 & Ethanol $10 \mathrm{mg} / 100 \mathrm{~mL}$, naproxen \\
\hline $\begin{array}{l}\text { Note: } \\
\text { ND = r } \\
\text { detect } \\
\text { *Unles } \\
\text { †Not o }\end{array}$ & $\begin{array}{l}\text { therwise specified, drugs in t } \\
\text { erwise specified. }\end{array}$ & cgonir & noto & $\begin{array}{l}\text { d, URP } \\
\text { titated. }\end{array}$ & $\mathrm{VC}=\mathrm{it}$ & r ven & $\mathrm{a}, \mathrm{MD}$ & nethyle & $=\mathrm{mbl}$ & $\begin{array}{l}\text { tamine, MAMP = methamphetamine, } \\
\text { omethylphenylpiperazine }, \text { trace }= \\
\text { available to permit quantitation. }\end{array}$ \\
\hline
\end{tabular}


deaths, it was not practical to access the medical records from each treating hospital. Second, although 16 of the patients were found to have serotonin syndrome, we are unable to comment on the presence of the syndrome in the 10 who were pronounced dead at the scene. Third, the presence of multiple synthetic amphetamines in all cases made it difficult to definitively identify PMMA as the drug responsible for death. However, the important role of PMMA in these deaths is emphasized by the known toxicity of the drug, and by the large number of deaths occurring in a short time frame. During the same 11-month period, there was only 1 methamphetamine-associated fatality and no deaths associated with either MDMA or amphetamine toxicity in Alberta (Dr. Graham Jones, Office of the Chief Medical Examiner, Edmonton, Alta.: personal communication, 2015). Although deaths from exposure to synthetic amphetamines other than PMMA periodically occur in Alberta and BC, the widespread availability and use of those drugs does not suggest that they are unique in terms of their lethality. What makes PMMA different is the cluster nature of related deaths, consistent with the extremely high toxicity of PMMA relative to other more common amphetamines. Furthermore, the concentration of PMMA in our case series was higher than that of other amphetamines in most cases and is similar to the concentration in previous studies describing PMMA-associated deaths.

\section{Table 5: Antemortem and postmortem concentrations of PMMA in whole blood $(n=25 / 27)^{*}$}

\begin{tabular}{|lc|}
\hline Blood sample & $\begin{array}{c}\text { Concentration, mg/L, } \\
\text { median (range) }\end{array}$ \\
\hline Antemortem blood & $1.43(0.11-3.27)$ \\
\hline Postmortem IVC and central blood & $2.84(0.14-4.88)$ \\
\hline Postmortem femoral and iliac blood & $4.41(2.17-15.7)$ \\
\hline $\begin{array}{l}\text { Note: IVC = inferior vena cava, PMMA = paramethoxymethamphetamine. } \\
\text { *Insufficient blood sample for quantitation in case 2; antemortem urine test } \\
\text { positive in case 7, but no postmortem blood test performed. }\end{array}$ \\
\hline
\end{tabular}

\section{Conclusion}

We describe 27 PMMA-associated deaths over an 11-month period in 2 provinces. Exposure to PMMA was characterized by serotonin syndrome, shock and multisystem organ failure. In addition to PMMA, multiple synthetic amphetamines were present on toxicologic analysis, which emphasizes the variability in the content of ecstasy powder and pills produced in clandestine laboratories. The potential for exposure to numerous sympathomimetic drugs of abuse has implications during the evaluation of patients. Clinicians must anticipate multiple clinical effects from the increased release of dopamine, serotonin, norepinephrine and other neurotransmitters.

\section{References}

1. Steele TD, Katz JL, Ricaurte GA. Evaluation of the neurotoxicity of N-methyl1-(4-methoxyphenyl)-2-aminopropane (para-methoxymethamphetamine, PMMA). Brain Res 1992;589:349-52.

2. Vevelstad M, Oiestad EL, Middelkoop G, et al. The PMMA epidemic in Norway: comparison of fatal and non-fatal intoxications. Forensic Sci Int 2012; 219:151-7.
3. Lin DL, Liu HC, Yin HL. Recent paramethoxymethamphetamine (PMMA) deaths in Taiwan. 7 Anal Toxicol 2007;31:109-13.

4. Chen WH, Chui C, Yin HL. The antemortem neurobehavior in fatal paramethoxymethamphetamine usage. Subst Abus 2012;33:366-72.

5. Johansen SS, Hansen AC, Muller IB, et al. Three fatal cases of PMA and PMMA poisoning in Denmark. 7 Anal Toxicol 2003;27:253-6.

6. Lurie Y, Gopher A, Lavon O, et al. Severe paramethoxymethamphetamine (PMMA) and paramethoxyamphetamine (PMA) outbreak in Israel. Clin Toxicol (Phila) 2012;50:39-43.

7. Becker J, Neis P, Rohrich J, et al. A fatal paramethoxymethamphetamine intoxication. Leg Med (Tokyo) 2003;5(Suppl 1):S138-41.

8. Refstad S. Paramethoxyamphetamine (PMA) poisoning; a 'party drug' with lethal effects. Acta Anaesthesiol Scand 2003;47:1298-9.

9. Dunkley EJ, Isbister GK, Sibbritt D, et al. The hunter serotonin toxicity criteria: simple and accurate diagnostic decision rules for serotonin toxicity. Q7M 2003;96:635-42.

10. Dykhuizen RS, Brunt PW, Atkinson P, et al. Ecstasy induced hepatitis mimicking viral hepatitis. Gut 1995;36:939-41.

11. Fidler H, Dhillon A, Gertner D, et al. Chronic ecstasy (3,4-methylenedioxymetamphetamine) abuse: a recurrent and unpredictable cause of severe acute hepatitis. 7 Hepatol 1996;25:563-6.

12. Acute kidney injury work group. Kidney disease: improving global outcomes (KDIGO). KDIGO clinical practice guideline for acute kidney injury. Kidney Int Suppl 2012;2:1-138.

13. Cervellin G, Comelli I, Lippi G. Rhabdomyolysis: historical background, clinical, diagnostic and therapeutic features. Clin Chem Lab Med 2010;48:749-56.

14. Nelson, LS, Lewin, NA. Antidysrhythmics. In: Nelson LS, Lewin NA, Howland MA, et al., editors. Goldfrank's toxicologic emergencies. 9th ed. New York: McGraw-Hill; 2011:925-35.

15. Liebelt, EL. Cyclic antidepressants. In: Nelson LS, Lewin NA, Howland MA, et al., editors. Goldfrank's toxicologic emergencies. 9th ed. New York: McGraw-Hill; 2011:1049-59

16. Prosser, JMHR. Cocaine. In: Nelson LS, Lewin NA, Howland MA, et al., editors. Goldfrank's toxicologic emergencies. 9th ed. New York: McGraw-Hill; 2011: 1091-102.

17. Clinical laboratory tests - reference values. Ottawa: Royal College of Physicians and Surgeons of Canada. Available: www.royalcollege.ca/portal/page /portal/rc/common/documents/exams/normal_values_e.pdf (accessed 2015 Feb. 13).

18. Lora-Tamayo C, Tena T, Rodriguez A. Amphetamine derivative related deaths. Forensic Sci Int 1997;85:149-57.

19. Glennon RA, Young R, Dukat M, et al. Initial characterization of PMMA as a discriminative stimulus. Pharmacol Biochem Behav 1997;57:151-8.

20. Pálenícek T, Balíková $M$, Rohanová $M$, et al. Behavioral, hyperthermic and pharmacokinetic profile of para-methoxymethamphetamine (PMMA) in rats. Pharmacol Biochem Behav 2011;98:130-9.

21. Staack RF, Fehn J, Maurer HH. New designer drug p-methoxymethamphetamine: studies on its metabolism and toxicological detection in urine using gas chromatography-mass spectrometry. 7 Chromatogr B Analyt Technol Biomed Life Sci 2003;789:27-41.

22. PMMA / Ecstasy. Alberta Health Services; 2012. Available: www.albertahealthservices .ca/6320.asp (accessed 2015 Feb. 13).

23. Potkins, M, Derworiz, C. 12th death linked to tainted ecstasy in BC and Alberta. National Post 2012 Jan. 31. Available: http://news.nationalpost.com /2012/01/31/12th-death-linked-to-tainted-ecstasy-in-b-c-and-alberta/ (accessed 2015 Feb. 13).

24. 8 deaths in Alberta linked to toxic methamphetamine. Huffington Post 2012 Jan. 31. Available: www.huffingtonpost.ca/2012/01/31/alberta-drug-deaths n_1245000.html (updated 2012 Feb. 1; accessed 2015 Feb. 13).

25. Bailey, I. Tainted ecstasy linked to five recent BC deaths. Globe and Mail [Toronto] 2012 Jan. 13. Available: www.theglobeandmail.com/news/british -columbia/tainted-ecstasy-linked-to-five-recent-bc-deaths/article4241434/ (updated 2012 Sept. 6; accessed 2015 Feb. 13).

26. 8 Alberta deaths linked to ecstasy-like drug. CBC News 2012 Jan. 31. Available: www.cbc.ca/news/canada/calgary/8-alberta-deaths-linked-to-ecstasy-like-drug -1.1166437 (updated 2012 Feb. 8; accessed 2015 Feb. 13).

27. PMMA confirmed in recent overdose. CTV News 2012 Jan. 30. Available: http ://calgary.ctvnews.ca/pmma-confirmed-in-recent-overdose-1.760909 (accessed 2015 Feb. 13).

28. PMMA is still very much at large. I was wrong, important info, plz read! In Bluelight [Web site]. 2012 Aug. 16. Available: www.bluelight.org/vb/archive /index.php/t-637525.html (accessed 2015 Feb. 13).

29. From the underground to the mainstream. In: CrystalMeth $B C$ [Web site]. Available: www.crystalmethbc.ca/modules.php? name $=$ News $\&$ file $=$ article $\&$ sid $=416$ (accessed 2015 Feb. 13)

30. CN BC. Ecstasy warnings continue. In: Ravewave [Web site]. 2012 Jan. 13 Available: www.rave.ca/sp/news_info/231716/canada/ (updated 2012 Jan. 16; accessed 2015 Feb. 13).

31. Update: Drug warning - PMMA contaminated ecstasy \& recent deaths. In: EmeraldCityEDM [Web site]. 2012 May 8. Available: http://emeraldcityedm .com/update-drug-warning-pmma-contaminated-ecstasy-recent-deaths/ (accessed 2015 Feb. 13) 
32. Five BC deaths linked to lethal chemical PMMA. In: TranceAddict Forums [Web site]. 2012 Jan. 14. Available: www.tranceaddict.com/forum/showthread .php? threadid=623796\&referrerid=2 (accessed 2015 Feb. 13).

33. Sorden, S. Deaths in Canada linked to PMMA mixed in Ecstasy. In: Fohn's Addiction [Web site]. 2012 Apr. 17. Available: http://johnsaddiction.com/3923-pmma -ecstasy-deaths/ (updated 2012 June 12; accessed 2015 Feb. 13).

34. Warning of PMMA laced ecstasy...esp if in BC. In: DMT-nexus [Web site]. 2012 Jan. 14. Available: www.dmt-nexus.me/forum/default.aspx? $g=$ posts $\& \mathrm{t}=28844$ (accessed 2015 Feb. 13).

35. Potent stimulant PMMA associated with ecstasy deaths. In: TPR: The Poison Review [Web site]. 2012 Jan. 14. Available: www.thepoisonreview.com/2012 /01/14/potent-stimulant-pmma-associated-with-ecstasy-deaths/ (accessed 2015 Feb. 13).

36. Coomber R. Dangerous drug adulteration - an international survey of drug dealers using the Internet and the World Wide Web (WWW). Int 7 Drug Policy 1997;8:71-81.

37. Ecstasy use in high risk populations. Centre for Addictions Research of BC. Available: http://carbc.ca/FactsStats/AODMonitoring/ProjectComponents /tabid/94/agentType/View/PropertyID/124/Default.aspx (accessed 2015 Feb. 13).

39. Morefield KM, Keane M, Felgate P, et al. Pill content, dose and resulting plasma concentrations of 3,4-methylenedioxymethamphetamine (MDMA) in recreational "ecstasy" users. Addiction 2011;106:1293-300.

40. Wood DM, Stribley V, Dargan PI, et al. Variability in the 3,4-methylenedioxymethamphetamine content of "ecstasy" tablets in the UK. Emerg Med 7 2011;28:764-5

41. Drug checking. In: Dance Safe [Web site]. Available: www.dancesafe.org /drug-checking/ (updated 2014; accessed 2015 Feb. 13).

Affiliations: Department of Emergency Medicine (Nicol, Yarema, Wishart), University of Calgary, Calgary, Alta.; Poison and Drug Information Service (Yarema), Alberta Health Services, Calgary, Alta.; Office of the Chief Medical Examiner (Jones), Edmonton, Alta.; School of Population and Public
Health (Buxton), University of British Columbia, Vancouver, BC; British Columbia Centre for Disease Control (Tzemis, Buxton), Vancouver, BC; Provincial Toxicology Centre (Martz), Vancouver, BC; British Columbia Drug and Poison Information Centre and Department of Emergency Medicine (Purssell), University of British Columbia, Vancouver, BC; Population, Public and Aboriginal Health, Alberta Health Services - Calgary Zone and Department of Community Health Sciences (MacDonald), University of Calgary, Calgary, Alta.; Environmental Health Services, British Columbia Centre for Disease Control and Canadian Field Epidemiology Program (Durigon), Public Health Agency of Canada, Ottawa, Ont.

Contributors: Mark Yarema was responsible for the study concept. Jennifer Nicol drafted the study protocol, and Mark Yarema, Graham Jones, Walter Martz, Roy Purssell, Judy MacDonald, Ian Wishart, Monica Durigon and Jane Buxton revised it. Jennifer Nicol, Ian Wishart and Despina Tzemis collected the data from the medical records. Despina Tzemis contributed to the interpretation of the data. Graham Jones and Walter Martz provided the toxicological findings. Jennifer Nicol performed the statistical analysis and drafted the manuscript, and all of the authors revised the manuscript critically for important intellectual content. All of the authors approved the final version accepted for publication and agreed to act as guarantors of the work.

Acknowledgements: The authors acknowledge Dr. Steven A. Persaud for assisting in the medical record review of the BC cases and Dr. Catherine $\mathrm{T}$. Elliott for providing input to the study protocol.

Supplemental information: For reviewer comments and the original submission of this manuscript, please see www.cmajopen.ca/content/3/1 /E83/suppl/DC1 